\title{
Oral squamous cell carcinoma (OSCC) - molecular, viral and bacterial concepts
}

\author{
Dorota Polz-Gruszka', Paweł Macieląg ${ }^{1}$, Sylwia Fołtyn'1, Małgorzata Polz-Dacewicz' \\ 1 Department of Virology, Medical University, Lublin, Poland \\ Polz-Gruszka D, Macieląg P, Fołtyn S, Polz-Dacewicz M. Oral squamous cell carcinoma (OSCC) - molecular, viral and bacterial concepts. J Pre- \\ Clin Clin Res. 2014; 8(2): 61-66. doi: 10.5604/18982395.1135651
}

\begin{abstract}
Head and neck cancers constitute the sixth most common malignant tumours worldwide, and are one of the majors problems of global public health. In the oral cavity there are several types of oral cancers, but around $90 \%$ are squamous cell carcinoma. Many different risk factors play a role in the etiology of head and neck cancer. The aim of this study is presentation from the aspect of molecular, viral and bacterial infection. Knowledge about all factors which influence the development of these malignances is essential for diagnostics and successful treatment.
\end{abstract}

\section{Key words}

oral squamous cell carcinoma, viruses, bacteria, genetic and epigenetic aspects

\section{INTRODUCTION}

Head and neck cancers constitute the sixth most common malignant tumours worldwide $[1,2]$. Each year, 650,000 new cases occur resulting in almost 350,000 cancer deaths. These malignancies arise from the epithelium of the nasal and oral cavity, paranasal sinus, pharynx and larynx. Oral cancer, a subtype of head and neck cancer, is any cancerous tissue growth located in the oral cavity. There are several types of oral cancers, but around $90 \%$ are squamous cell carcinoma. Oral carcinogenesis is a multistep process modulated by endogenous and environmental factors.

Epidemiology. Oral squamous cell carcinoma (OSCC) is one of the most common malignancies leading to death among head and neck squamous cell carcinoma (HNSCC) worldwide.

An estimated 400,000 new cases of cancer of the lip and oral cavity and pharynx were diagnosed across the world in 2008 (3\% of the total) [3].

In developed countries, the incidence affects 6.9 males and 2.4 females, and mortality -2.3 males and 0.6 females [4], whereas in developing countries the incidence is 4.6 males and 2.6 females, and mortality -2.7 males and 1.5 females. Relative survival rates are five years (\%) for OSCC among individuals aged 15 and older in the USA (60.8) and Europe: 53.6 in England, 45.9 - Denmark, 40.3 - Austria, 36.7 Poland, 41.5 - Belgium, and 60.7\% in Germany. Oral SCC more frequently affects males than females $(\mathrm{M}: \mathrm{F}=1.5: 1)$. Oral cancer incidence is strongly related to age. The probability of developing oral SCC increases with the period of exposure to risk factors, and increasing age adds a further dimension of age-related mutagenic and epigenetic changes. In the USA, the median age of diagnosis of oral SCC is 62 years. However, the incidence of oral SCC in persons under 45 yeasrs of age is increasing. The European incidence rates of lip and oral cavity cancer in 2008 is presented in Table 1.

In Poland, malignant tumors are the second cause of death, after cardiovascular diseases, and in 2010 accounted for

Address for correspondence: Dorota Polz-Gruszka, Department of Virology, Medical University, ul Chodźki 1, 20-093 Lublin, Poland

E-mail: dorota.polz@umlub.pl

Received: 29 July 2014; accepted: 03 November 2014
Table 1. Lip and Oral Cavity Cancer - European Age - standardized incidence rates per 100,000; EU 27 countries [4]

\begin{tabular}{|c|c|c|}
\hline COUNTRY & MALE & FEMALE \\
\hline Hungary & 22.3 & 4.9 \\
\hline Spain & 15.3 & 3.8 \\
\hline Slovakia & 15.8 & 3 \\
\hline Portugal & 13.4 & 3 \\
\hline Luxembourg & 12.6 & 3.7 \\
\hline France (Metropolitan) & 11.3 & 4.8 \\
\hline Belgium & 11.3 & 4.1 \\
\hline Estonia & 10.6 & 4.3 \\
\hline Denmark & 9.8 & 5 \\
\hline Lithuania & 11.6 & 2.4 \\
\hline Romania & 12.6 & 1.2 \\
\hline Slovenia & 10.2 & 3.1 \\
\hline EU-27 & 9.7 & 3.4 \\
\hline The Netherlands & 8 & 5.1 \\
\hline Czech Republic & 9.2 & 3.7 \\
\hline Poland & 10.2 & 2.2 \\
\hline Malta & 8.9 & 3.5 \\
\hline Bulgaria & 9.3 & 2.3 \\
\hline Germany & 8.1 & 3.1 \\
\hline Italy & 8.1 & 3.1 \\
\hline Finland & 6.8 & 4 \\
\hline Ireland & 7.7 & 3 \\
\hline Sweden & 6.2 & 4.1 \\
\hline UK & 6.8 & 3.4 \\
\hline Australia & 7 & 2.9 \\
\hline Latvia & 7.9 & 1.8 \\
\hline Cyprus & 3.3 & 2.3 \\
\hline Greece & 3.4 & 2 \\
\hline
\end{tabular}

$26 \%$ of deaths in males and $23 \%$ in females [5]. In Poland in 2010, 2,709 men were diagnosed with lip, mouth or throat cancer, and 1,763 died. Cancers of the lip, oral cavity and throat account for $9.84 \%$ of all cancers in males and $1.4 \%$ in females. Oral cancer is second to cancer of the larynx among malignant tumours of the head and neck. 
Lifestyle risk factors. The effect of some etiological factors is well established in the literature, such as consumption of tobacco and alcohol, poor oral hygiene and inapriopriate dietary habits $[6,7]$. However, approximately $15-20 \%$ of all oral cancer cases occur in patients without the traditional risk factors, reflecting in numerous cases of OSCC in nonsmokers and non-alcohol drinkers.

Head and neck cancers are correlated with a combination of cigarette smoking and alcohol drinking. The link between cancer and smoking was first reported in the 1950s by Wynder et al. [8]. Consumption of tobacco (smoking and chewing) is a important risk factor for head and neck cancer. The most susceptible organ to the effects of tobacco smoking is the larynx. In the absence of tobacco use, the association between alcohol consumption and the risk of head and neck cancer is weak, stronger only for laryngeal and pharyngeal cancer, it is apparent only at high doses. Alcohol and tobacco consumption together have a synergistic effect.

Inapropriate dietary habits, such as low fruit and vegetable intake, are risk factors for head and neck cancer. There are various micronutrients with known antioxidant and anticarcinogenic properties, among them: vitamins $\mathrm{C}$ and E, flavonoids, phytosterols, folates, as well as dietary fibres, which play a role in reducing the risk of cancers of the upper aerodigestive tract [11]. It is estimated that there is an overall $49 \%$ reduction in oral cancer risk for each portion of fruit eaten per day and overall a $50 \%$ reduction for vegetable consumption. The most important in protection against cancer are 4 botanical groups of fruits and vegetables: Leguminosae (beans and peas), Rosaceae (apples, strawberries, peaches, nectarines), Solanaceae (tomatoes and peppers) and Umbelliferae (carrots) [12, 13].

HPV (Human papilloma virus) infection can spread during sexual contacts; therefore, sexual behaviours are associated with the head and neck cancer [14].

Some authors suggest an association between marijuana and cannabis smoking, head and neck cancers and oral premalignant lesions, but the carcinogenicity of tetrahydrocannabinol is still not clear [15].

Oncogenes and tumour suppressor genes. An oncogene is a kind of abnormal gene that predisposes cells to develop into cancers. Their correct version (proto-oncogenes) are commonly found in human genetic material and perform the functions necessary to maintain the integrity of tissues and organs. Among other things, they control cell division and differentiation processes and also regulate their suicidal death (apoptosis). Mutated proto-oncogenes are over-expressed, and thereby stimulate cell proliferation. This leads to tumour formation and cancer development. Protooncogenes have no transcriptional activity of their own, but may change in the active oncogenes by mutations (caused by carcinogens) or by interaction of viruses. The occurrence of DNA damage and expression of the oncogenes lead to initiation of expression of the suppressor genes, which are antagonistic to the oncogenes [16].

In 1971, Knudson [17] presented a theory according to which the beginning the process of carcinogenesis requires the simultaneous occurrence of mutations in the proto-oncogene and tumour suppressor gene. The coincidence activating proto-oncogene mutations and mutations blocking the activity of the tumour suppressor gene, according to Knudson and called the theory of two events, is now the canon for explaining the molecular basis of the carcinogenesis process. Oncogenes represent a class of genes of diverse tumour activity in various tumour types. In the case of oral cancer, the family of oncogenes activation of Ras (H-, K-, N-ras), c-myc, erbB-1/ EGFR, D1 and FHIT PRAD-1/cyclin is recognized. This list is not definitive and there are ongoing studies to identify further oncogenes that may play a role in cancers of the head and neck, or in the various stages of the disease. The products of expression of oncogenes are activated oncoprotein which are responsible for the initiation of malignant transformation. Oncoprotein causes the cells remaining in the resting phase of the cell cycle to start division for the proliferation of cells; therefore, identifies this group of growth factors and proteins responsible for the regulation of the cell cycle.

An important role in OSCC is played by external growth factors [18], including such factors as: epidermal (EGF), fibroblast (FGV), tumour growth factor alpha (TGF-alfa) and platelet derived growth factor (PDGF). Some of these factors are frequently over-expressed in oral cancers. The overexpression of the EGFR is often accompanied by the synthesis of its ligands TGF-alfa and EGF. The interaction between these receptors and its ligands initiates a cascade of events.

Oral Cancer Over-expressed 1 (ORAOV1) is a candidate protooncogene in a variety of human squamous cell carcinomas (SCCs) [19]. ORAOV1 has been identified at chromosomal band 11q13, and was supposed to be a primary driving force behind 11q13 gene amplification, and regarded as a candidate oncogene with a role in the development and progression of various human SCCs. In subsequent years, however, several clinical studies showed that the expression level of ORAOV1 was tightly correlated with prognosisrelated clinicopathological parameters and clinical grades in several SCCs, such as oesophageal squamous cell carcinoma and oral squamous cell carcinoma (OSCC) [20]. Further functional studies showed that ORAOV1 may have an important role in the tumour genesis of OSCC by taking part in the regulation of cell growth and tumour angiogenesis. It is therefore suggested that ORAOV1 may be a valuable biological marker in SCCs.

Chromosomal band 11q13 is one of the most frequently amplified regions in OSCC. Using positional candidate gene analysis, Oral Cancer Over-expressed 1 (ORAOV1), also called Tumor Amplified and Over-expressed Sequence 1 (TAOS1), was identified within this region, and is presumed to be a candidate oncogene in OSCC. ORAOV1 amplification is significantly associated with larger tumour size, lymph node metastasis, poor histological differentiation and advanced clinical stage of OSCC. All these findings suggest an oncogenic potential of ORAOV1 in OSCC, and therefore a possible molecular marker in diagnosis, prognosis and treatments of OSCC. ORAOV1 can be targeted for therapeutic manipulation in treating OSCC $[21,22]$.

CCND1 gene located on chromosome 11. CCND1 gene is a member of the cyclin G1 family responsible for inducing cyclin D1 expression. Rearragemant and overexpression of CCND1 gene are consistent feathers of tumors. The correlation between its over-expression and tumour cell progression of many cancers, including those located in the head and neck, has been well-documented. Chromosomal locus in tumours in which this gene is located is amplified, as shown by classical cytogenetics research, and were further confirmed by fluorescence in situ hybridization (FISH), and comparative 
genomic hybridization (CGH). Amplification of CCND1 locus causes excessive production of cyclin D1. It plays an important role in the mechanism of the formation of miRNA regulation (the function of miRNAs appears to be in gene regulation). As a result, this leads to an increase in the rate of cell proliferation, include epithelial, from which the majority of oral cancers originate. It has been shown that amplification of the 11q13 region is a poor prognosis for patients with squamous cell carcinoma of the larynx. Interestingly, according to the mapping results of chromosome 11q13, the distance between CCND1 and ORAOV1 is less than $12 \mathrm{~kb}$ [22].

Another oncogenes associated with cancer of the oral cavity are TAOS1 and EMS1 [23]. These genes were equated as two important target oncogenes for driving 11q13 amplification, and their contributions to oral carcinogenesis. Researchers have investigated amplifications of TAOS1 and EMS1 genes and their relations to clinicopathological variables in premalignant lesions (leukoplakias) and primary OSCC. TAOS1 amplification, beginning from mild-dysplastic epithelia, occurred in $33.3 \%$ of leukoplakias and $51.5 \%$ of OSCC. EMS1 amplification, beginning from moderatedysplastic epithelia, occurred in $20 \%$ of leukoplakias and $57.6 \%$ of OSCC. Both gene amplifications were significantly related to different stages of oral carcinogenesis $(p<0.05)$. Both TAOS1 and EMS1 amplifications were significantly associated with tumour grading and staging. The test results suggested potential roles in oral carcinogenesis, and that TAOS1 might be involved earlier than EMS1. Both genes might be candidate biomarkers for diagnosis and prognosis in OSCC.

On the other hand, in the human genome there are suppressor genes of neoplastic transformation (antioncogenes). Their purpose is to stop the metamorphosis by checking cells, inhibiting cell proliferative cycle, and eliminating those that contain the mutated DNA by apoptosis. This is a process of programmed cell death, generally characterized by distinct morphological characteristics and energydependent biochemical mechanisms. The many different types of apoptotic pathways contain a multitude of different biochemical components, many of them not yet understood. This complicated process requires the interaction of regulatory proteins. They are essential to the initiation of this process, encoded by tumour suppressor genes. The next stage is the activation of enzymes of the ICE family (interleukin-1beta-converting enzyme), called caspases, the activation of which depends inter alia on protein Bcl-2 [24].

In cancer of the larynx and pharynx a certain regularity can be observed, a good prognosis, the possibility of limited larynx resection during the operation, and a positive response to chemo-and radiotherapy are associated with low expression of the protein $\mathrm{Bcl}-\mathrm{xl}$, while a poor prognosis with a high expression of the protein. Insufficiency apoptosis is most commonly associated with negative mutations of the p53 gene [25]. Among the best known antioncogenes hindering the development of cancers of the oral cavity, are included p53, p16 and Rb1. In humans, the p53 gene is located on the short arm of chromosome 17 (17p13), and normally operates as a tumour suppressor gene (wild type p53). The p53 gene product is a short half-life protein, TP53, synthesized in the cytoplasm, and senescent cells contain trace amounts of the protein. The level of p53 mRNA and p53 protein levels reach a peak just before the onset of DNA replication, which is the interfacial G1/S cell cycle. TP53 has a region locating the nucleus (nuclear localization signals), through which it passes to the nucleus at the beginning of the S phase and briefly accumulates in it. This protein has many mechanisms with an anticancer function, and plays a role in apoptosis, genomic stability, and inhibition of angiogenesis. P53 gene mutation is one of the most common genetic changes recognized in laryngeal cancer cells, also mutations in head and neck cancer are more frequent than in other cancers. In the case of p53, the primary mechanism responsible for blocking the expression is a gene mutation. Part mutation causes an unstable or non-functional protein, unable to inhibit the proliferation adopted by the cell [26]. The situation is different issue inactivation of tumor suppressor genes p16 and Rb. The latest results of cytogenetic studies show that inactivation of the p16 gene is regulated by the epigenetic principle. Hypermethylation of the promoter the p16 gene leading to a lack of its transcriptional activity. In contrast, inhibition of the $\mathrm{Rb}$ gene (13q14 chromosomal location) is the result of deletion or microdeletion of the whole or part of the long arm of chromosome 14 [27].

Oncogenic viruses. The role of viruses in the development of oral squoamous cell carcinoma has been proposed in many studies $[28,29,30]$. The most frequently studied are Human papilloma virus (HPV), Epstein-Barr virus (EBV) and Herpes Simplex virus type 1 (HSV-1).

An original observation and hypothesis that implicated HPV as a risk factor in a subset of oral cancers was presented by Syrjanen et al. in 1983 [31]. Since then, several studies have focused on HPV detection in oral cancer, but the results have been controversial. A recent study by Syrjänen [32] showed a strong association between the presence of HPV DNA specifically HPV16 and OSCC. This meta-analysis showed that HPV significantly increases the risk for OSCC, compared with controls (OR 3.98; 95\% CI: 2.62-6.02).

HPVs specifically target the undifferentiated proliferative basal cells of epithelial mucosa. HPV proteins, especially the oncoproteins E6 and E7 of the high risk HPVs (HRHPVs), interact with different degrees of affinity with host cell proteins to disturb the normal epithelial differentiation and apoptosis by stimulating cellular proliferation, DNA synthesis and inhibition of cell cycle regulators [33].

Data provided in the literature suggest that the role of EBV in OSCC may vary according to geographical regions. The prevalence of EBV in oral samples varies widely in different studies. Most south-east Asian studies found a high prevalence of EBV and concluded an etiological role of EBV in OSCC. In an Egyptian population this was also supported by immunohistochemical detection of LMP1, the EBV antigen associated with transforming activity [34]. North American studies, as well as West and NorthEuropean studies, regularly report lower prevalences of EBV, and conclude that the etiological role of EBV is doubtful in OSCC. Jalouli et al. $[35,36]$ studied formalin-fixed paraffinembedded tissue samples obtained from patients with oral cancers. These findings illustrate that the prevalence of HSV, HPV and EBV infections is common and may influence of oral cancer development. Liu et al. [37] demonstrated the frequent presence of HHV-6 in oral squamous cell carcinoma. The authors suggested that HHV- 6 possibly play a role in the pathogenesis of oral squamous cell carcinoma.

Researchers have suggested the possible involvement of $\mathrm{HCV}$ in diseases outside the liver and oral cavity exposed to 
Table 2. The most common genes silenced by promoter methylation [49]

\begin{tabular}{|c|c|c|c|}
\hline Gene & Locus & Function & Alterations \\
\hline$A B O$ & $9 q 34$ & Blood group antigen & Hypermethilation \\
\hline$A P C$ & $5 q 21$ & Signal transduction & Hypermethilation \\
\hline ATM & $11 q 22-q 23$ & Tumor suppressor & Hypermethilation \\
\hline$C / E B P a$ & $19 q 13$ & Tumor suppressor & Hypermethilation \\
\hline CDKN2A & 9 p21 & Cell cycle & $\mathrm{LOH}$, hypermethilation \\
\hline CRABP2 & $1 q 21$ & $\begin{array}{l}\text { Nuclear transcriptional } \\
\text { regulator }\end{array}$ & Hypermethilation \\
\hline DAPK & $9 q$ & Apoptosis & Hypermethilation \\
\hline$D C C$ & $18 q 21$ & Tumor suppressor & Hypermethilation \\
\hline DKK3 & $11 p$ & Transcriptional regulator & Hypermethilation \\
\hline E-cadherin & $16 q 22$ & Signal transduction & Hypermethilation \\
\hline EDNRB & $13 q 22$ & Signal transduction & Hypermethilation \\
\hline GSTP1 & $11 q 13$ & $\begin{array}{l}\text { Detoxification of } \\
\text { carcinogens }\end{array}$ & Hypermethilation \\
\hline H3K4 & $1 \mathrm{q} 21.2$ & Histone & Hypermethilation \\
\hline HIN1 & $12 \mathrm{p} 13$ & Tumour suppressor & Hypermethilation \\
\hline $\mathrm{Hm} / \mathrm{h} 1$ & $3 p 21$ & DNA repair & Hypermethilation \\
\hline LHX6 & $9 q 33$ & Transcriptional regulator & Hypermethilation \\
\hline MGMT & $10 q 26$ & DNA repair & Hypermethilation \\
\hline MINT family & / & / & Hypermethilation \\
\hline $\operatorname{miR} 137$ & $1 \mathrm{p} 21.3$ & Tumour suppressor & Hypermethilation \\
\hline miR193a & $17 q 11.2$ & Tumour suppressor & Hypermethilation \\
\hline MX1 & $21 q 22$ & I & Hypermethilation \\
\hline p14 & $9 p 21$ & Apoptosis & LOH, hypermethilation \\
\hline p15 & 9 p21 & Cell cycle & $\begin{array}{l}\text { LOH, deletion, mutation, } \\
\text { hypermethilation }\end{array}$ \\
\hline p16 & $9 p 21$ & Cell cycle & $\begin{array}{l}\mathrm{LOH}, \text { mutation, deletion, } \\
\text { hypermethilation }\end{array}$ \\
\hline p53 & $17 p 13$ & Tumour suppressor & $\begin{array}{l}\text { Mutation, } \\
\text { hypermethilation }\end{array}$ \\
\hline$p 73$ & $1 \mathrm{p} 36$ & Apoptosis & Hypermethilation \\
\hline PTEN & $10 q 23$ & Tumor suppressor & Hypermethilation \\
\hline RARB2 & $17 q 21$ & $\begin{array}{l}\text { Nuclear transcriptional } \\
\text { Regulator }\end{array}$ & Hypermethilation \\
\hline RASSF-1 & $3 p 21$ & Apoptosis & Hypermethilation \\
\hline$R b$ & $13 q 14$ & Tumour suppressor & $\begin{array}{l}\text { Hypermethilation, } \\
\text { mutation }\end{array}$ \\
\hline RUNX3 & $1 \mathrm{p} 36$ & Transcriptional regulator & Hypermethilation \\
\hline SFRP1 & $8 p 11.21$ & Transcriptional regulator & Hypometilation \\
\hline $\begin{array}{l}\text { SFRP1-2- } \\
4-5\end{array}$ & $\begin{array}{l}8 p 11.214 q 31.3 \\
7 p 14.110 q 24.1\end{array}$ & Transcriptional regulator & Hypermethilation \\
\hline TCF21 & $6 q 23-q 24$ & $\begin{array}{l}\text { epithelial-mesenchymal } \\
\text { interactions }\end{array}$ & Hypermethilation \\
\hline THBS1 & $15 q 15$ & $\begin{array}{l}\text { cell-to-cell and cell-to- } \\
\text { matrix interactions }\end{array}$ & Hypermethilation \\
\hline TIMP3 & $22 q 12$ & $\begin{array}{l}\text { epithelial-mesenchymal } \\
\text { interactions }\end{array}$ & Hypermethilation \\
\hline WIF1 & $12 q 14$ & Transcriptional regulator & Hypermethilation \\
\hline$\sigma-14-3-3$ & 1 p36 & Signal transduction & Hypermethilation \\
\hline
\end{tabular}

$\mathrm{HCV}$ viruses. Gandolfo et al. [38] found a very high prevalence of anti-HCV antibodies in patients with oral lichen planus. Other authors suggest that HCV may be involved in the development of SCC and oral lichen planus [39].
Bacterial infections. Bacterial infections have been linked to malignancies. Several mechanisms for possible bacterial association in carcinogenesis may include chronic infection by evasion of immune system and immune suppression, induction of chronic inflammation, direct or indirect interference with eukaryotic cell cycle and signaling pathways, or via metabolism of potential carcinogenic substances.

Pushalkar et. al [40] studied oral microbiota in tumour and non-tumour tissues of patients with oral squamous cell carcinoma, and indicated that from a total of 1,200 sequences characterized, 80 bacterial species/phylotypes were detected representing six phyla: Firmicutes, Bacteroidetes, Proteobacteria, Fusobacteria, Actinobacteria and uncultivated TM7. The following bacterial species were observed: Streptococcus sp., Peptostreptococcus stomatis, Streptococcus salivarius, Streptococcus gordonii, Gemella haemolysans, Gemella morbillorum, Johnsonella ignava and Streptococcus parasanguinis. Porphyromonas gingivalis and Fusobacterium nucleatum have attributes consistent with a role in cancer development and progression [41]. Both $P$. gingivalis and $F$. nucleatum establish chronic infections that involve intracellular persistence within epithelial cells, can spread systemically and cause extra-oral infections. The detection of $P$. gingivalis or F. nucleatum in precancerous lesions could be used as a poor prognosis indicator. Improved oral hygiene and treatment of periodontitis may be useful in limiting the development or spread of cancer. J. ignava can be a predicted new pathogen, not detected in earlier studies, and known to be associated with gingivitis and periodontitis [42]. Bolz et al. [43] isolated the most different bacteria groups in the biofilms of OSCC patients. The highest resistance rate to common antibiotics in maxillofacial surgery was detected in biofilms of OSCC patients. Anand et al. [44], in a pilot study, suggest a possible association of $H$. pylori and increased risk of oral cancer.

Epigenetic changes. Epigenetics is the most rapidly expanding field in the biological science in recent years. Epigenetic instability is a change in the expression of genes, not directly linked with the DNA sequence. In 1942, Waddington defined the term of epigenetics as 'the branch of biology that studies the causal interactions between genes and their products, which bring the phenotype into being' Currently, there are two main epigenetic changes: DNA methylation (hypo-or hyper-methylation) and chromatin remodeling, involving changes within the histone proteins. This effect can be reversed by treatment with an appropriate chemical substances, unlike the genetic changes that are irreversible [45].

Hypomethylation is typically associated with overexpression of oncogenes, and hypermethylation inhibits the transcription of the tumour suppressor gene. Methylation occurs primarily during the $S$ phase of the cell cycle and is based on the covalent attachment of methyl groups (-CH3) to the nitrogenous nucleobases (around $\mathrm{CpG}$ dinucleotide). In the human genome, approximately $70 \%$ of $\mathrm{CpG}$ islands have a methyl group attached to the cytosine. However, this process does not occur in areas essential for the basic processes of the cell. This includes the $\mathrm{CpG}$ island located at the 5 'ends of the promoter regions of genes. In the case of neoplastic transformation, it is noticeable by an abnormal methylation global genome hypomethylation and hypermethylation of the promoter specific for the tumour suppressor genes. DNA 
methylation is catalysed by a family of DNA methyltransferase enzymes (DNMTs) [46].

Another disorder leading to epigenetic regulation of gene expression observed in cancer cells is the modification of histone proteins. Histone proteins may undergo posttranslational modification which consists in the addition of various supplementary molecules or functional groups (such as methyl, acetyl, phosphate, protein, ubiquitin) to the amino acids: lysine and arginine. The effect of posttranslational modifications of histones to the degree chromatin condensation and gene expression depend not only on the type of modification (methylation, acetylation, phosphorylation, etc.), but is also determined by the location of this modification on the histones protein. This process affects the condensation or relaxation of the chromatin structure. DNA becomes more or less accessible to transcription factors and polymerases, which results in a decrease or increase in the level of gene expression [47].

The knowledge of the epigenetics of cancers may the development of several inhibitors of DNA methyltransferase successfully used in the therapy. Jithesh et al. [48] have reported an association between 'CIMP- high' and worse prognosis. These data suggest that the application of epigenetic biomarkers may be available for the further development of OSCC therapy [48]. Hypermethylation, and the consequent silencing of several tumour suppressor genes of more than 40 genes, has been identified in OSCC (Tab. 3). The genes found hypermethylated in OSCC cover a wide range of cellular processes, including cell cycle control (p16, p15), apoptosis (p14, DAPK, p73 and RASSF1A), Wnt signalling (APC, WIF1, RUNX3), cell-cell adhesion (E-cadherin), and DNA-repair (MGMT and hMLH1) [49].

Table 3. The most common epigenetic alterations [49]

\begin{tabular}{|c|c|c|}
\hline Epigenetic change & Putative mechanism & Biological consequence \\
\hline \multirow[t]{2}{*}{ DNA hypomethylation } & $\begin{array}{l}\text { Activation of cellular } \\
\text { oncogenes }\end{array}$ & $\begin{array}{l}\text { Increased proliferation, } \\
\text { growth advantage }\end{array}$ \\
\hline & $\begin{array}{l}\text { Activation of transposable } \\
\text { element }\end{array}$ & $\begin{array}{l}\text { Genomic instability, } \\
\text { transcriptional noise }\end{array}$ \\
\hline DNA hypermethylation & $\begin{array}{l}\text { De novo hypermethylation } \\
\text { of CpG islands within } \\
\text { gene promoters leading } \\
\text { to silencing of tumour } \\
\text { suppressors and cancer- } \\
\text { associated genes }\end{array}$ & $\begin{array}{l}\text { Genomic and } \\
\text { chromosomal instability, } \\
\text { increased proliferation, } \\
\text { growth advantage }\end{array}$ \\
\hline Loss of imprinting (LOI) & $\begin{array}{l}\text { Reactivation of silent } \\
\text { alleles, biallelic expression } \\
\text { of imprinted genes }\end{array}$ & $\begin{array}{l}\text { Expansion of precursor cell } \\
\text { population }\end{array}$ \\
\hline $\begin{array}{l}\text { Relaxation of } \\
\text { X-chromosome } \\
\text { inactivation }\end{array}$ & $\begin{array}{l}\text { Mechanisms unknown but } \\
\text { appears to be age-related }\end{array}$ & $\begin{array}{l}\text { Altered gene dosage, } \\
\text { growth advantage }\end{array}$ \\
\hline \multirow[t]{2}{*}{ Histone acetylation } & Gain-of-function & $\begin{array}{l}\text { Activation of tumor } \\
\text { promoting genes }\end{array}$ \\
\hline & Loss-of-function & $\begin{array}{l}\text { Defects in DNA repair and } \\
\text { checkpoints }\end{array}$ \\
\hline Histone deacetylation & $\begin{array}{l}\text { Silencing of tumour } \\
\text { suppressor genes }\end{array}$ & $\begin{array}{l}\text { Genomic instability, } \\
\text { increased proliferation }\end{array}$ \\
\hline Histone methylation & $\begin{array}{l}\text { Loss of heritable patterns of } \\
\text { gene expression ('cellular } \\
\text { memory') }\end{array}$ & $\begin{array}{l}\text { Genomic instability, } \\
\text { growth advantage }\end{array}$ \\
\hline $\begin{array}{l}\text { MicroRNAs (miRNAs) } \\
\text { amplification in cancer }\end{array}$ & Function as oncogenes & Neoplastic transformation \\
\hline $\begin{array}{l}\text { MicroRNAs (miRNAs) } \\
\text { deletion in cancer }\end{array}$ & $\begin{array}{l}\text { Function as tumour } \\
\text { suppressors }\end{array}$ & Neoplastic transformation \\
\hline
\end{tabular}

\section{CONCLUSIONS}

Head and neck cancers are one of the major problems of public health worldwide. Knowledge about all factors which influence the development of these malignances is essential for diagnostics and successful treatment. Further studies to determine the role of viral and bacterial infections, genetic and epigenetic changes and their possible interactions are under consideration.

\section{REFERENCES}

1. Mascolo M, Siano M, Ilardi G, Russo D, Merolla F, De Rosa G, Staibano S. Epigenetic Disregulation in Oral Cancer. Int J Mol Sci. 2012; 13(2): 2331-2353. doi: 10.3390/ijms13022331.

2. Blot WJ, McLaughlin JK, Winn DM, Austin DF, Greenberg RS, PrestonMartin S, et al. Smoking and drinking in relation to oral and pharyngeal cancer. Cancer Res. 1988; 48(11): 3282-3287.

3. American Cancer Society. Global Cancer Facts \& Figures 2nd Edition. Atlanta: American Cancer Society; 2011.

4. Ferlay J, Shin HR, Bray F, Forman D, Mathers C, Parkin DM. Estimates of worldwide burden of cancer in 2008. GLOBOCAN 2008. Int J Cancer. 2008; 127(12): 2893-2911.

5. Wojciechowska U, Didkowska J, Zatoński W. Nowotwory złośliwe w Polsce w 2010r. Cancer in Poland in 2010. Warszawa, Centrum Onkologii Instytut im. Marii Skłodowskiej-Curie, 2012 (in Polish).

6. Majchrzak E, Szybiak B, Wegner A, Pienkowski P, Pazdrowski J, et al. Oral cavity and oropharyngeal squamous cell carcinoma in young adults: a review of the literature. Radiol Oncol. 2014; 48(1): 1-10.

7. Guha N, Boffetta P, Wunsch FV, Eluf Neto JE, Shangina O, Zaridze D, et al. Oral health and risk of squamous cell carcinoma of the head and neck and esophagus: Results of two multicentric case-control studies. Am J Epidemiol. 2007; 166(10): 1159-1173.

8. Wynder EL, Bross IJ, Day E. Epidemiological approach to the etiology of cancer of the larynx. J Am Med Assoc. 1956; 160(16): 1384-1391.

9. Maier H, Dietz A, Gewelke U, Heller WD, Weidauer H. Tobacco and alcohol and the risk of head and neck cancer. Clin Investig. 1992; 70(3-4): 320-327.

10. Hashibe M, Brennan P, Chuang SC, Boccia S, Castellsauge X, Chen C, et al. Interaction between tobacco and alcohol use and the risk of head and neck cancer: Pooled analysis in the International Head and Neck Cancer Epidemiology Consortium. Cancer Epidemiol Biomarkers Prev. 2009; 18: 541-550.

11. Bosetti C, Gallus S, Trichopoulou A, Talamini R, Franceschi S, Negri E, LaVecchia C. Influence of the Mediterranean diet on the risk of cancers of the upper aerodigestive tract. Cancer Epidemiol Biomarkers Prev. 2003; 12: 1091-1094

12. Pavia M, Pileggi C, Nobile CG, Angelillo IF. Association between fruit and vegetable consumption and oral cancer: a meta-analysis of observational studies. Am J Clin Nutr. 2006; 83: 1126-1134.

13. Freedman ND, Park Y, Subar AF, Hollenbeck AR, Leitzmann MF, Schatzkin A, Abnet C, et al. Fruit and vegetable intake and head and neck cancer risk in a large United States prospective cohort study. Int J Cancer. 2008; 122(10): 2330-2336.

14. Heck JE, Berthiller J, Vaccarella S, Winn DM, Smith EM, Shan'gina O, et al. Sexual behaviours and the risk of head and neck cancers: a pooled analysis in the International Head and Neck Cancer Epidemiology (INHANCE) consortium. Int J Epidemiol. 2010; 39(1): 166-181.

15. Marks MA, Chaturvedi AK, Kelsey K, Straif K, Berthiller J, Schwartz $\mathrm{SM}$, et al. Association of marijuana smoking with oropharyngeal and oral tongue cancers: pooled analysis from the INHANCE consortium. Cancer Epidemiol Biomarkers Prev. 2014; 23(1): 160-171. doi: 10.1158/1055-9965.

16. Felsher DW. Oncogene addiction versus oncogene amnesia: perhaps more than just a bad habit? Cancer Res. 2008; 1,68(9): 3081-3086. doi: 10.1158/0008-5472.CAN-07-5832.

17. Knudson, A. Mutation and cancer: statistical study of retinoblastoma. Proc Natl Acad Sci USA. 1971; 68: 820-823.

18. Khan MH, Mishu MP, Imam ST. Current molecular concept of oral carcinogenesis and invasion. Medicine Today 2010; 22: 38-42.

19. Jiang L, Zeng X, Yang H, Wang Z, Shen J, Bai J, et al. Oral cancer overexpressed 1 (ORAOV1): a regulator for the cell growth and tumor angiogenesis in oral squamous cell carcinoma. Int J Cancer. 2008; 15: 123(8): 1779-1786. doi: 10.1002/ijc.23734. 
20.Zhai C, Li Y, Mascarenhas C, Lin Q, Li K, Vyrides I, et al. The function of ORAOV1/LTO1, a gene that is overexpressed frequently in cancer: essential roles in the function and biogenesis of the ribosome. Oncogene. 2014; 23-33(4): 484-494. doi: 10.1038/onc.2012.604.

21. Katoh M. Evolutionary conservation of CCND1-ORAOV1-FGF19FGF4 locus from zebrafish to human. Int J Mol Med. 2003; 2(1): 45-50.

22. Huang X, Gollin SM, Raja S, Godfrey TE. High-resolution mapping of the 11q13 amplicon and identification of a gene, TAOS1, that is amplified and overexpressed in oral cancer cells. Proc Natl Acad Sci. 2002; 99: 11369-11374.

23.Xia J, Chen Q, Li B, Zeng X. Amplifications of TAOS1 and EMS1 genes in oral carcinogenesis: association with clinicopathological features. Oral Oncol. 2007; 43(5): 508-514.

24. Szukała K, Szyfter K, Kujawski M. Function of tumor suppressor genes in head and neck cancer. Współcz Onkol. 2003; 7(4): 240-246.

25. Watling DL, Gown AM, Coltrera M. Overexpression of P53 in head and neck cancer. Head Neck. 1992; 14: 437-444. doi:10.1002/hed.2880140603.

26. Kalfert D, Celakovsky P, Laco J, Ludvikova M. The Role of Protein p16INK4a in glottic laryngeal squamous cell carcinoma. Pathol Oncol Res. 2014; (Epub ahead of print).

27. Macha MA, Rachagani S, Pai P, Gupta S, Lydiatt WM, Smith RB, et al. MUC4 regulates cellular senescence in head and neck squamous cell carcinoma through p16/Rb pathway. Oncogene. 2014. doi: 10.1038/ onc.2014.102 (Epub ahead of print).

28. Metgud R, Astekar M, Verma M, Sharma A. Role of viruses in oral squamous cell carcinoma. Oncol Rev. 2012; 6: 164-170.

29. Hillbertz NS, Hirsch JM, Jalouli J, Jalouli M, Sand L. Viral and molecular aspects of oral cancer. Anticancer Res. 2012; 32: 4201-4212.

30. Sand L, Jalouli J. Viruses and oral cancer. Is there a link? Microbes and Infection 2014; 1 : 1-8

31. Syrjänen KJ, Syrjänen SM, Lamberg MA, Pyrhönen S. Human papillomavirus (HPV) involvement in squamous cell lesions of the oral cavity. Proc Finn Dent Soc. 1983; 79(1): 1-8.

32. Syrjänen K, Syrjänen S. Detection of human papillomavirus in sinonasal carcinoma: systematic review and meta-analysis. Human Pathol. 2013, 44: 983-991.

33. Doorbar J. Papillomavirus life cycle organization and biomarker selection. Dis Markers. 2007; 23(4): 297-313.

34. Scully C. Oral cancer aetiopathogenesis; past, present and future aspects. Med. Oral. Patol Cir Bucal. 2011; 1(16): 306-311.

35. Jalouli J, Ibrahim SO, Sapkota D, Jalouli MM, Vasstrand EN, Hirsch JM, Larsson PA, et al. Presence of human papilloma virus, herpes simplex virus and Epstein-Barr virus DNA in oral biopsies from Sudanese patients with regard to toombak use. J Oral Pathol. Med. 2010; 39: 599-604.
36. Jalouli J, Jalouli MM, Sapkota D, Ibrahim SO, Larsson PA, Sand L. Human papilloma virus, herpes simplex virus and Epstein-Barr virus in oral squamous cell carcinoma from eight different countries. Anticancer Res. 2012; 32(2): 571-580.

37. Liu JL, Xu ZK, Zhao Y, Jin Y, Dai YM, Yao K. Relationship between human herpesvirus 6 infection and oral squamous cell carcinoma. Chinese Journal of experimental and clinical virology 2003; 17(4): 334-336.

38. Gandolfo S, Carbone M, Carozzo M, Gallo V. Oral lichen planus and hepatitis $\mathrm{C}$ virus (HCV) infection: is there a relationship? J Oral Pathol Med. 1994; 23: 119-122.

39. Nagao Y, Sata M, Itoh K, Tanikawa K, Kameyama T. Quantitative analysis of HCV RNA and genotype in patients with chronic hepatitis C accompanied by oral lichen planus. Eur J Clin Invest. 1996; 26: 495-498.

40. Pushalkar S, Ji X, Yihong Li, Estilo Ch, Yegnanarayana R, Singh B, et al. Comparison of oral microbiota in tumor and non-tumor tissues of patients with oral squamous cell carcinoma. BMC Microbiol. 2012; 12: 144. doi: 10.1186/1471-2180-12-144.

41. Whitmore SE, Lamont RJ. Oral bacteria and cancer. PLoS Pathog. 10(3): 1003933. doi:10.1371/journal.ppat.1003933.

42. Mazzio E, Smith B, Soliman K. Evaluation of endogenous acidic metabolic products associated with carbohydrate metabolism in tumor cells. Cell Biol Toxicol. 2010; 26(3): 177-188. doi: 10.1007/s10565-0099138-6.

43. Bolz J, Dosá E, Schubert J, Eckert A. Bacterial colonization of microbial biofilms in oral squamous cell carcinoma. Clin Oral Invest. 2014; 8: 409-414. doi 10.1007/s00784-013-1007-2.

44. Anand D, Vineeta S, Mridula S, Royana S, Manoj P. Helicobacter pylori and oral cancer; possible association in a preliminary case control study. Asian Pac J Cancer Prev. 2011; 12: 1333-1336.

45. Mund C, Lyko F. Epigenetic cancer therapy: Proof of concept and remaining challenges. Bioassays 2010; 32(11): 949-957.

46. González-Ramírez I, García-Cuellar C, Sánchez-Pérez Y, GranadosGarcía M. DNA methylation in oral squamous cell carcinoma: molecular mechanisms and clinical implications. Oral Dis. 2011; 17(8): 771-778. doi: 10.1111/j.1601-0825.2011.01833.x.

47. Marcinkiewicz KM, Gudas LJ. Altered epigenetic regulation of homeobox genes in human oral squamous cell carcinoma. Exp Cell Res. 2014; 320(1):128-143. doi: 10.1016/j.yexcr.2013.09.011.

48. Jithesh PV, Risk JM, Schache AG, Dhanda J, Lane B, Liloglou T, Shaw RJ. The epigenetic landscape of oral squamous cell carcinoma. BJC. 2013; 108: 370-379.

49. Mascolo M, Siano M, Ilardi G, Russo D, Merolla F, De Rosa G, Staibano S. Epigenetic disregulation in oral cancer. Int J Mol Sci. 2012; 13(2): 2331-2353. 